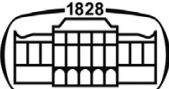

AKADÉMIAI KIADÓ

\title{
Simple HPLC method for rapid quantification of nicotine content in e-cigarettes liquids
}

\author{
ALA A. ALHUSBAN* $\odot$ and SAMAH A. ATA
}

\section{Acta Chromatographica}

33 (2021) 3, 302-307

DOl:

$10.1556 / 1326.2020 .00832$

(c) 2020 The Authors

\section{ORIGINAL RESEARCH} PAPER

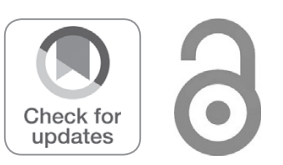

*Corresponding author. Department of Pharmacy, Faculty of Pharmacy, AlZaytoonah University of Jordan, P. 0. Box, 130, 11733, Amman, Jordan. Tel.: $+96264291511 \times 310$; fax: +96264291432 .

E-mail: Ala.Alhusban@zuj.edu.jo
Department of Pharmacy, Faculty of Pharmacy, Al-Zaytoonah University of Jordan, Amman, Jordan

Received: August 9, 2020 - Accepted: August 10, 2020

Published online: September 14, 2020

\section{ABSTRACT}

Electronic nicotine delivery systems (ENDs) are gaining popularity in Jordan as alternatives to tobacco cigarettes with an estimation of $10 \%$ of tobacco smokers switching to ENDs. Since nicotine is toxic and highly addictive substance, it is important to develop and validate an easy and rapid analytical method to accurately measure nicotine level in e-liquids. A simple high performance liquid chromatographyphotodiode array detection (HPLC-PDA) method was developed and validated for rapid determination of the actual nicotine content in 11 of the most popular e-liquids brands available in the Jordanian market and compared to the nicotine levels appeared in the labeled packaging. The new method of analysis showed an excellent linearity with correlation factor equal to 0.9994 with analytical range between 100 and 1,000 $\mu \mathrm{g} / \mathrm{mL}$, and Limit of detection (LOD) and Limit of quantification (LOQ) of 32.6 $\mu \mathrm{g} / \mathrm{mL}$ and $98.9 \mu \mathrm{g} / \mathrm{mL}$, respectively. The results showed that the actual measured nicotine concentrations ranged from 0 to $25.81 \mathrm{mg} / \mathrm{mL}$ with percent deviation ranged from $63.1 \%$ less than to $3.24 \%$ more than the labeled concentration on packaging. And more than $10 \%$ deviation difference in actual nicotine concentrations versus labeled were found in 9 of the 11 e-liquid products (82\%). In conclusion, nicotine labelling among e-liquids products have not accurately reflect the actual content which may have potential negative impact on users.

\section{KEYWORDS}

nicotine, e-cigarettes, e-liquid, HPLC, labeling, ENDs, health hazard

\section{INTRODUCTION}

Tobacco smoke contains numerous hazardous components and contributes to serious adverse outcomes [1]. In Jordan, tobacco smoking is widely popular among the general population. In 2015, the World Health Organization (WHO) announced that Jordan has ranked 2 nd in the world with smokers percentage of $70.2 \%$ among males older than 15 years and ranked 6th with percentage of $40.5 \%$ for both genders among countries with the highest smoking rates [2]. Electronic nicotine delivery systems (ENDs) use is increasing worldwide and most adults' users perceptions and reasons for ENDs are for tobacco smoking cessation [3]. Moreover, recent randomized controlled trials have revealed that ENDs are more effective for smoking cessation than nicotine replacement [4] and nicotine patches [5]. Therefore, tobacco smokers in Jordan have started switching to use ENDs instead of regular tobacco smoking. Till now, no data is available regarding the prevalence of ENDs use. Yet, an estimation of 1 from 10 regular tobacco smokers have either attempted or switched to ENDs.

Several studies have revealed that e-liquids containing nicotine used in ENDs are greatly variable than what are stated on labels [6-15]. Hence, Jordan Food and Drug Administration (JFDA) has recently issued specific legislations for tobacco and nicotine delivery systems including ENDs licensing and regulation in July 2019, which necessitate the utilization of reliable analytical methods to control these products and their contents for quality and safety.

Nicotine, an alkaloid composed of pyridine and pyrrolidine rings, affects large variety of biological functions including gene expression, regulation of hormone secretion and enzyme activities [16]. In addition to being highly addictive, nicotine adversely affects many organs 
Table 1. The description of brands of e-liquids used for analysis (obtained from Jordan)

\begin{tabular}{|c|c|c|c|c|}
\hline $\begin{array}{l}\text { Brand } \\
\text { of e- } \\
\text { liquid }\end{array}$ & $\begin{array}{c}\text { Date of } \\
\text { purchase }\end{array}$ & $\begin{array}{l}\text { Date of } \\
\text { expiration }\end{array}$ & $\begin{array}{l}\text { Labeled } \\
\text { level of } \\
\text { nicotine } \\
(\mathrm{mg} / \mathrm{mL})\end{array}$ & Flavor \\
\hline $\begin{array}{c}\text { e-liquid } \\
1\end{array}$ & $\begin{array}{c}10 \\
\text { September, } \\
2019\end{array}$ & $\begin{array}{c}\text { October, } \\
2021\end{array}$ & 25 & Tobacco \\
\hline $\begin{array}{l}\text { e-liquid } \\
2\end{array}$ & $\begin{array}{c}23 \\
\text { September, } \\
2019\end{array}$ & May, 2021 & 20 & Fruit \\
\hline $\begin{array}{c}\text { e-liquid } \\
3\end{array}$ & $\begin{array}{c}23 \\
\text { September, } \\
2019\end{array}$ & July, 2021 & 10 & Watermelon \\
\hline $\begin{array}{c}\text { e-liquid } \\
4\end{array}$ & $\begin{array}{c}23 \\
\text { September, } \\
2019\end{array}$ & $\begin{array}{c}\text { September, } \\
2021\end{array}$ & 20 & Strawberry \\
\hline $\begin{array}{l}\text { e-liquid } \\
5\end{array}$ & $\begin{array}{c}25 \\
\text { September, } \\
2019\end{array}$ & June, 2021 & 25 & $\begin{array}{c}\text { Lemon- } \\
\text { mint }\end{array}$ \\
\hline $\begin{array}{c}\text { e-liquid } \\
6\end{array}$ & $\begin{array}{c}25 \\
\text { September, } \\
2019\end{array}$ & May, 2021 & 25 & Apple \\
\hline $\begin{array}{c}\text { e-liquid } \\
7\end{array}$ & $\begin{array}{c}25 \\
\text { September, } \\
2019\end{array}$ & $\begin{array}{c}\text { January, } \\
2021\end{array}$ & 25 & Tobacco \\
\hline $\begin{array}{c}\text { e-liquid } \\
8\end{array}$ & $\begin{array}{c}30 \\
\text { September, } \\
2019\end{array}$ & $\begin{array}{c}\text { September, } \\
2021\end{array}$ & 25 & Tobacco \\
\hline $\begin{array}{c}\text { e-liquid } \\
9\end{array}$ & $\begin{array}{c}30 \\
\text { September, } \\
2019\end{array}$ & $\begin{array}{c}\text { February, } \\
2021\end{array}$ & 3 & $\begin{array}{c}\text { Tropical } \\
\text { fruit }\end{array}$ \\
\hline $\begin{array}{c}\text { e-liquid } \\
10\end{array}$ & $\begin{array}{c}30 \\
\text { September, } \\
2019\end{array}$ & May, 2021 & 3 & Milk vanilla \\
\hline $\begin{array}{c}\text { e-liquid } \\
11\end{array}$ & $\begin{array}{l}03 \text { October, } \\
2019\end{array}$ & July, 2021 & 0 & Grape \\
\hline $\begin{array}{l}\text { Ref. e- } \\
\text { liquid }\end{array}$ & $\begin{array}{l}\text { 07 October, } \\
2019\end{array}$ & NA & 15 & No flavor \\
\hline
\end{tabular}

including heart, reproductive system, lungs, kidneys, in addition to its carcinogenic potential [17]. Nicotine is a toxic poison and has rapid action on organs especially peripheral and central nervous systems. In severe poisoning, tremors, prostration, cyanosis, dyspnea, convulsion, progression to collapse and coma and even death may arise from paralysis of respiratory muscles and/or central respiratory failure with the fatal dose of $30-40 \mathrm{mg} / \mathrm{m}^{3}$ for $30 \mathrm{~min}$, assuming a breathing rate of $50 \mathrm{~L}$ per minute and $100 \%$ absorption [18].

Nicotine concentration has been determined by several analytical techniques including gas chromatography with flame ionization detector (GC-FID) [9], and gas chromatography-mass spectrometry (GC-MS) $[8,10]$. Since LC is a workhorse technique used for efficient and tedious analytical procedures [19-21]. It has been employed successfully for nicotine quantification in e-liquids such as liquid chromatography-mass spectrometry (LC-MS) [6, 7], in addition to HPLC with photodiode array detection (HPLC-PDA) $[13,14]$.
As the aim of our research group is to seek pharmaceutical products safety [22], the aim of this study was to develop and validate an easy and straightforward HPLC method for rapid determination of nicotine content in 11 of the most common e-liquids brands available in the Jordanian market and to compare the levels of actual nicotine with the labeled packaging to investigate both safety and quality.

\section{MATERIALS AND METHODS}

\section{E-liquids and chemicals}

All reagents were analytical grade reagents obtained from Sigma-Aldrich unless otherwise stated. Eleven samples from the most popular brands of e-liquids were obtained locally from Jordanian market. A reference e-liquid was prepared in the lab comprising propylene glycol, glycerol and pure nicotine (Alfa Aesar, UK). Table 1 shows the detailed description of each of e-liquid brands and are indicated as eliquid 1-11. Nicotine reference standard for calibration was purchased from Sigma-Aldrich (St. Louis, MO, USA).

\section{Instrumentation and HPLC-PDA analytical conditions}

Waters 2690 Alliance HPLC system equipped with a Waters 996 photodiode array detector (Milford, MA, USA) was employed for method development, validation and samples analysis. The analytical column used was $\mathrm{C}_{18}$-Thermo $(4.6 \times 250 \mathrm{~mm}, 5 \mu \mathrm{m})$. The Mobile phase consisted of $0.1 \%$ triethylamine in water buffer and acetonitrile (70\%:30\%) at $\mathrm{pH}=7.0$ in isocratic conditions and ambient temperature and was delivered at a flow rate of $1 \mathrm{~mL} / \mathrm{min}$. Nicotine was identified at UV wavelengths between 210 and $400 \mathrm{~nm}$ and quantifications was carried out at $254 \mathrm{~nm}$.

\section{Calibration standards, quality control (QC) and samples preparations}

Calibration curve $(n=3)$ was constructed for nicotine measurement from six standard solutions namely: 100, 200, $400,600,800$, and $1,000 \mu \mathrm{g} / \mathrm{mL}$. The standard solutions were prepared by a dilution of proper amount from stock standard solution $(1 \mathrm{mg} / \mathrm{mL})$ with methanol and were stored at $4{ }^{\circ} \mathrm{C}$. The QC's samples were prepared at 3 levels as $\mathrm{QC}_{\mathrm{L}}$ low $(300 \mu \mathrm{g} / \mathrm{mL}), \mathrm{QC}_{\mathrm{M}}$ medium $(700 \mu \mathrm{g} / \mathrm{mL})$, and $\mathrm{QC}_{\mathrm{H}}$ high $(950 \mu \mathrm{g} / \mathrm{mL})$, all were triplicate. Each of the diluted solutions was filtered using $0.22 \mu \mathrm{m}$ syringe filter then $10 \mu \mathrm{L}$ aliquot were injected.

A $100 \mu \mathrm{L}$ of each e-liquid samples (triplicate) was added to $1.9 \mathrm{~mL}$ methanol and sonicated for $5 \mathrm{~min}$ then vortexed for $2 \mathrm{~min}$. Each sample was filtered using $0.22 \mu \mathrm{m}$ syringe filter then $10 \mu \mathrm{L}$ sample was injected. The calibration curve covering the range $100-1,000 \mu \mathrm{g} / \mathrm{mL}$ for the analytes was prepared to validate the method linearity.

\section{Method validation}

The analytical method was validated as follow: 
Table 2. Parameters of the calibration curve for the employed nicotine standards of the chromatographic conditions for HPLC/ PDA detector

\begin{tabular}{lc}
\hline Parameter & Value \\
\hline Nicotine standards $t_{\mathrm{R}}$ average $(\mathrm{min}) \pm$ & $4.790 \pm 0.046$ \\
$\mathrm{SD}$ & $y=9951.6 x-198370$ \\
Calibration curve equation & 0.9994 \\
Determination coefficient $\left(R^{2}\right)$ & $32.6 \mu \mathrm{g} / \mathrm{mL}$ \\
LOD & $98.9 \mu \mathrm{g} / \mathrm{mL}$ \\
LOQ & $99.2 \%$ \\
Within-run accuracy & $1.82 \%$ \\
Within-run precision & $101.4 \%$ \\
Between-run accuracy & $4.1 \%$ \\
Between-run precision & \\
\hline
\end{tabular}

Selectivity. Method selectivity is important to distinguish the target analyte from endogenous substances and other compounds in e-liquid samples. The selectivity of the method was evaluated using a prepared e-liquid with zero nicotine concentration by comparing the peak signal at the target analyte retention time in blank samples with the peak signal at the target analyte retention time at limit of quantitation (LOQ) sample.

Precision and accuracy. Within-run and between-run accuracy and precision were evaluated at three replicates of three QCs levels in one analytical run and three consecutive days respectively.

Limit of detection (LOD) and Limit of quantification (LOQ). The calculation of both LOD and LOQ were based on the Standard Deviation (SD) of Intercepts of the calibration curves $(\sigma)$ and the slope of the calibration curves $(S)$ for nicotine standards $(n=3)$. The LOD and LOQ were expressed according to the following equations (standards and blanks injected 3 times consecutively):

$$
\begin{aligned}
& \mathrm{LOD}=\frac{(3.3 \times \sigma)}{S} \\
& \mathrm{LOQ}=\frac{(10 \times \sigma)}{S}
\end{aligned}
$$

The LOQ is the lowest reliable concentration in the calibration curve that could be quantified by the analytical method. In order to further validate the LOQ of the method experimentally, the analyte signal at the analyte retention time of a blank matrix was compared to the analyte signal at the same retention time of an LOQ sample prepared from the same matrix.

\section{RESULTS AND DISCUSSION}

\section{Method development and validation}

The development and validation of an analytical method for quantification of nicotine in e-liquid samples has met the acceptance criteria of FDA guidelines [23]. In which the sample processing and preparation involved only a simple and effective dilution procedure and also no carry over was reported of the analyte. Moreover, the method was selective where no interfering peaks at the retention time of nicotine were observed. Likewise, the method showed excellent linearity with correlation factor equal to 0.9994 over the analytical range of $100-1,000 \mu \mathrm{g} / \mathrm{mL}$ with calculated LOD and LOQ of 32.6 and $98.9 \mu \mathrm{g} / \mathrm{mL}$, respectively. Moreover, within-run and between-run accuracy and precision were $99.2,1.82 \%$ and $101.4,4.1 \%$ respectively. This indicates that the developed method is reliable, accurate and reproducible. Table 2 summarizes the parameters of the calibration curves

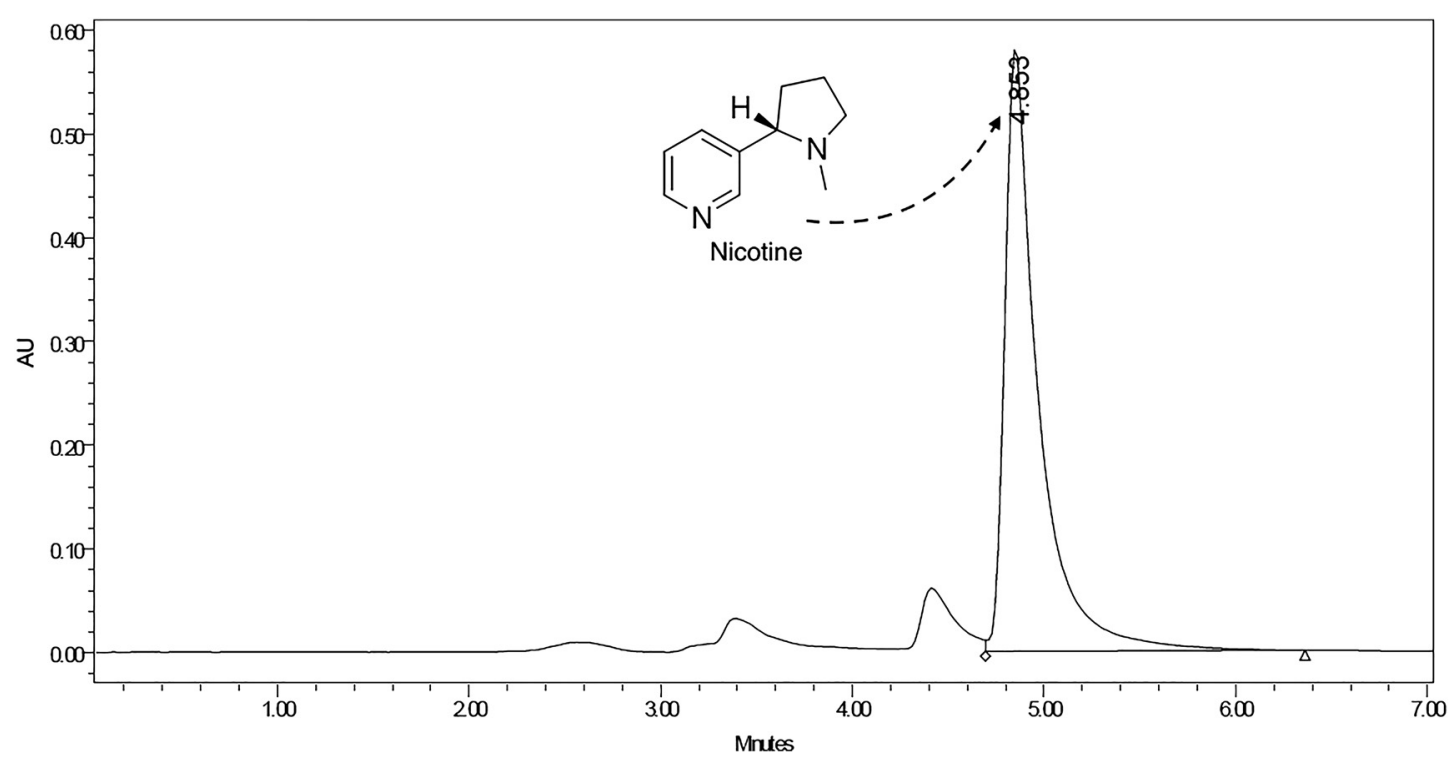

Fig. 1. Chromatogram of an e-liquid sample (nicotine $t_{R}=4.853 \mathrm{~min}$ ) with injection volume: $10 \mu \mathrm{L}$; column: $\mathrm{C}_{18}$-Thermo $(4.6 \times 250 \mathrm{~mm}, 5$ $\mu \mathrm{m})$ : detector: UV wavelengths between 210 and $400 \mathrm{~nm}$, quantifications was carried out at $254 \mathrm{~nm}$ 
Table 3. The comparison of the measured concentration of nicotine with the labeled packaging in terms of \% Deviation from label $(n=3)$

\begin{tabular}{lccc}
\hline $\begin{array}{c}\text { Brand } \\
\text { of e- } \\
\text { liquid }\end{array}$ & $\begin{array}{c}\text { Labeled level } \\
\text { of nicotine }\end{array}$ & $\begin{array}{c}\text { Measured nicotine } \\
\text { concentration } \\
\text { (Triplicate average } \\
\pm \text { SD) }\end{array}$ & $\begin{array}{c}\text { Deviation } \\
\text { from label }^{\text {a }} \\
(\%)\end{array}$ \\
\hline e-liquid 1 & 25 & $19.11 \pm 1.28$ & -23.6 \\
e-liquid 2 & 20 & $14.19 \pm 0.72$ & -29.1 \\
e-liquid 3 & 10 & $6.38 \pm 0.91$ & -36.2 \\
e-liquid 4 & 20 & $16.86 \pm 1.08$ & -15.7 \\
e-liquid 5 & 25 & $18.27 \pm 1.63$ & -26.9 \\
e-liquid 6 & 25 & $22.58 \pm 1.45$ & -9.7 \\
e-liquid 7 & 25 & $25.81 \pm 2.24$ & +3.24 \\
e-Liquid & 25 & $22.42 \pm 1.67$ & -10.3 \\
8 & & $3.69 \pm 0.41$ & -63.1 \\
e-liquid 9 & 10 & $1.75 \pm 0.10$ & -41.6 \\
e-liquid & 3 & Not detected & 0 \\
10 & & & \\
e-liquid & 0 & $19.85 \pm 0.83$ & -0.75 \\
11 & & & \\
Ref. e- & 20 & & \\
liquid & & & \\
\hline
\end{tabular}

${ }^{\mathrm{a}}$ Deviation from label $=($ measured value - labelled value $) \times 100 /$ labelled value.

for the employed nicotine standards and validation results. Fig. 1 illustrates the chromatogram of one of the analyzed eliquids showing nicotine peak around 4.9 min.

\section{Nicotine concentrations in the most popular brands e- liquids}

This study concerns in developing and validating an easy and straightforward HPLC method for rapid determination of nicotine content in different commercial e-liquids. Consequently, 11 samples of the most popular e-liquids brands available in the Jordanian market were tested and their concentrations were compared to the labeled nicotine levels in packaging. Table 3 lists the comparison of the measured concentration of nicotine with the labeled packaging.

The percent deviation of nicotine concentration from labeled concentration was determined using following equation (1):

Deviation from label $=\frac{(\text { measured value }- \text { lebelled value }) \times 100}{\text { lebelled value }}$.

The printed labeling of nicotine concentrations from 11 brands of e-liquids ranged from 0 to $25 \mathrm{mg} / \mathrm{mL}$. However, variations existed in actual nicotine concentrations between bottles of e-liquids. The results showed that the measured concentration ranged from 0 to $25.81 \mathrm{mg} / \mathrm{mL}$, with maximum percent deviation equal to $63.1 \%$ less than the labelled concentration in one sample and $3.24 \%$ more than the labelled concentration of nicotine in another sample.

The differences between actual and labeled nicotine content have been determined in several studies and presented as percent deviation of actual nicotine concentration from labeled concentration and are summarized in Table 4. The percentages of e-liquids in which the actual quantified nicotine concentrations that deviated by more than $\pm 10 \%$ from the manufacturer labels were 10\% [24], 18\% [15], 52\% [12], 56\% [25], 63\% [26], 65\% [27], and 67\% [9]. In this study, more than $\pm 10 \%$ deviations were detected in 9 out of 11 e-liquids (82\%) which are more than what stated in previous similar studies. Since Jordan is relatively new market for ENDs, most manufacturers and sellers obviously lack adequate knowledge of quality and safety of e-liquids. However, the new regulations issued by JFDA handle ENDs as medication in terms of quality and safety. Yet, special attention should be made in controlling all products available in the market. And urgent requirement for countrywide labeling standards for such products and need of measurement of concentration levels of nicotine in all products in the market.

Table 4. Summary of literature findings of actual nicotine levels in e-liquids compared to labeling

\begin{tabular}{|c|c|c|c|c|c|c|c|}
\hline literature & Matrix & $\begin{array}{l}\text { Analysis } \\
\text { technique }\end{array}$ & $\begin{array}{l}\text { e-liquid } \\
\text { samples } \\
\text { number }\end{array}$ & $\begin{array}{c}\text { Nicotine level } \\
\text { labeled }(\mathrm{mg} / \mathrm{mL})\end{array}$ & $\begin{array}{c}>10 \% \text { difference } \\
\text { between actual and } \\
\text { labeled nicotine conc. }\end{array}$ & $\begin{array}{l}\text { Percent } \\
\text { deviation }\end{array}$ & Country \\
\hline $\begin{array}{c}\text { Etter et al. } \\
\text { [24] }\end{array}$ & $\begin{array}{l}\text { e-cigarette } \\
\text { liquid }\end{array}$ & $\begin{array}{l}\text { UHPLC- } \\
\text { DAD }\end{array}$ & 20 & $6-30$ & 2 & $\begin{array}{l}-15 \text { to } \\
21 \%\end{array}$ & Sweden \\
\hline $\begin{array}{l}\text { Davis et al. } \\
\text { [27] }\end{array}$ & $\begin{array}{l}\text { e-cigarette } \\
\text { liquid }\end{array}$ & $\begin{array}{l}\text { HPLC- } \\
\text { DAD }\end{array}$ & 54 & $0-18$ & 35 & $\begin{array}{c}-1.3 \text { to } \\
89.7 \%\end{array}$ & USA \\
\hline $\begin{array}{l}\text { Kim et al. } \\
\text { [15] }\end{array}$ & $\begin{array}{l}\text { e-cigarette } \\
\text { liquid }\end{array}$ & GC-TSD & 32 & $0-18$ & 6 & $\begin{array}{c}-32.2 \text { to } \\
3.3 \%\end{array}$ & Korea \\
\hline $\begin{array}{l}\text { Farsalinos } \\
\quad \text { et al. [12] }\end{array}$ & $\begin{array}{l}\text { e-cigarette } \\
\text { liquid }\end{array}$ & GC-FID & 21 & $12-18$ & 11 & $\begin{array}{l}-21 \text { to } \\
22.1 \%\end{array}$ & Greece \\
\hline $\begin{array}{l}\text { Peace et al. } \\
\text { [9] }\end{array}$ & $\begin{array}{l}\text { e-cigarette } \\
\text { liquid }\end{array}$ & HPLC-MS & 27 & $6-22$ & 18 & $\begin{array}{c}-36 \text { to } \\
31 \%\end{array}$ & USA \\
\hline $\begin{array}{l}\text { Raymond } \\
\text { et al. [26] }\end{array}$ & $\begin{array}{l}\text { e-cigarette } \\
\text { liquid }\end{array}$ & $\begin{array}{l}\text { HPLC- } \\
\text { DAD }\end{array}$ & 35 & 18 & 22 & $\begin{array}{c}-35 \text { to } \\
52 \%\end{array}$ & USA \\
\hline $\begin{array}{l}\text { Bennani } \\
\text { et al. [25] }\end{array}$ & $\begin{array}{l}\text { e-cigarette } \\
\text { liquid }\end{array}$ & $\begin{array}{l}\text { HPLC - } \\
\text { DAD }\end{array}$ & 32 & $3-24$ & 18 & $\begin{array}{c}-100 \text { to } \\
3.3 \%\end{array}$ & Morocco \\
\hline
\end{tabular}




\section{CONCLUSION}

The developed HPLC-PDA method was successfully applied for rapid determination of nicotine content, in less than $5 \mathrm{~min}$, in 11 widespread e-liquids with LOD and LOQ of 32.6 and $98.9 \mu \mathrm{g} / \mathrm{mL}$, respectively. The validated method was straightforward, accurate and precise over a wide range of nicotine concentrations of e-liquids in the market. A variation in nicotine concentrations exist between the labeled and actual content. And more than $10 \%$ difference in actual nicotine concentrations versus labeled was found in 9 of the 11 e-liquid products $(82 \%)$ which necessitate the urgent need for labeling standards for these products in terms of nicotine content.

Funding source: This work was supported by the Deanship of Scientific Research at Al-Zaytoonah University of Jordan (2019-2020/23/6) and (2017-2018/28/19).

\section{REFERENCES}

1. Taujenis, L.; Olšauskaite, V.; Padarauskas, A. Determination of nicotine and three minor alkaloids in tobacco by hydrophilic interaction chromatography-tandem mass spectrometry. Acta Chromatogr. 2015, 27, 373-85.

2. WHO. Prevalence of Tobacco Smoking, 2015. https://www.who. int/gho/tobacco/use/en/, accessed 30th May, 2020.

3. Romijnders, K. A.; Van Osch, L.; De Vries, H.; Talhout, R. Perceptions and reasons regarding e-cigarette use among users and non-users: a narrative literature review. Int. J. Env. Res. Pub. He. 2018, 15, 1190.

4. Erly, B. K.; Prochazka, A. V. E-cigarettes were more effective than nicotine replacement for smoking cessation at 1 year. Ann. Internal Med. 2019, 170, JC50.

5. Hajek, P.; Phillips-Waller, A.; Przulj, D.; Pesola, F.; Myers Smith, K.; Bisal, N.; Li, J.; Parrott, S.; Sasieni, P.; Dawkins, L. A randomized trial of e-cigarettes versus nicotine-replacement therapy. N. Eng. J. Med. 2019, 380, 629-37.

6. Liu, X.; Joza, P.; Rickert, B. Analysis of nicotine and nicotine-related compounds in electronic cigarette liquids and aerosols by liquid chromatography-tandem mass spectrometry. Beiträge zur Tabakforschung Int./Contrib. Tob. Res. 2017, 27, 154-67.

7. Aszyk, J.; Kubica, P.; Kot-Wasik, A.; Namieśnik, J.; Wasik, A. Comprehensive determination of flavouring additives and nicotine in e-cigarette refill solutions. Part I: Liquid chromatography-tandem mass spectrometry analysis. J. Chromatogr. A 2017, 1519, 45-54.

8. Aszyk, J.; Woźniak, M. K.; Kubica, P.; Kot-Wasik, A.; Namieśnik, J.; Wasik, A. Comprehensive determination of flavouring additives and nicotine in e-cigarette refill solutions. Part II: Gas-chromatographymass spectrometry analysis. J. Chromatogr. A 2017, 1517, 156-64.

9. Peace, M. R.; Baird, T. R.; Smith, N.; Wolf, C. E.; Poklis, J. L.; Poklis, A. Concentration of nicotine and glycols in 27 electronic cigarette formulations. J. Anal. Toxicol. 2016, 40, 403-7.

10. Pagano, T.; DiFrancesco, A. G.; Smith, S. B.; George, J.; Wink, G.; Rahman, I.; Robinson, R. J. Determination of nicotine content and delivery in disposable electronic cigarettes available in the United States by gas chromatography-mass spectrometry. Nicotine Tob. Res. 2016, 18, 700-7.

11. Goniewicz, M. L.; Hajek, P.; McRobbie, H. Nicotine content of electronic cigarettes, its release in vapour and its consistency across batches: Regulatory implications. Addiction 2014, 109, 500-7.

12. Farsalinos, K. E.; Gillman, I.; Melvin, M. S.; Paolantonio, A. R.; Gardow, W. J.; Humphries, K. E.; Brown, S. E.; Poulas, K.; Voudris, $\mathrm{V}$. Nicotine levels and presence of selected tobacco-derived toxins in tobacco flavoured electronic cigarette refill liquids. Int. J. Env. Res. Pub. He. 2015, 12, 3439-52.

13. Gholap, V. V.; Kosmider, L.; Halquist, M. S. A standardized approach to quantitative analysis of nicotine in e-liquids based on peak purity criteria using high-performance liquid chromatography. J. Anal. Methods Chem. 2018, 2018.

14. Palazzolo, D.; Nelson, J. M.; Hudson, Z. The use of HPLC-PDA in determining nicotine and nicotine-related alkaloids from e-liquids: A comparison of five e-liquid brands purchased locally. Int. J. Env. Res. Pub. He. 2019, 16, 3015.

15. Kim, S.; Goniewicz, M. L.; Yu, S.; Kim, B.; Gupta, R. Variations in label information and nicotine levels in electronic cigarette refill liquids in South Korea: Regulation challenges. Int. J. Env. Res. Pub. He. 2015, 12, 4859-68.

16. Yildiz, D. Nicotine, its metabolism and an overview of its biological effects. Toxicon 2004, 43, 619-32.

17. Mishra, A.; Chaturvedi, P.; Datta, S.; Sinukumar, S.; Joshi, P.; Garg, A. Harmful effects of nicotine. Indian J. Med. Paediatr. Oncol.: Off. J. Indian Soc. Med. Paediatr. Oncol. 2015, 36, 24.

18. CDC. The National Institute for Occupational Safety and Health (NIOSH), 2014. https://www.cdc.gov/niosh/idlh/54115.html, accessed 2nd May, 2020.

19. Karvaly, G. B.; Tekes, K.; Szimrók, Z.; Fürész, J.; Kuča, K.; Kalász, H. A fieldable, high-throughput, cost-efficient high performance liquid chromatography-ultraviolet absorption detection (HPLC-UV) method for the quantitation of bispyridinium quaternary aldoxime cholinesterase reactivators in blood. Acta Chromatogr. 2020. ahead of print. https://doi.org/10.1556/1326.2020.00781.

20. Alhusban, A. A.; Tarawneh, O. A.; Dawabsheh, S. O.; Alhusban, A. A.; Abumhareb, F. W. Liquid chromatography-tandem mass spectrometry for rapid and selective simultaneous determination of fluoroquinolones level in human aqueous humor. J. Pharmacol. Tox. Met. 2019, 97, 36-43.

21. Zinjad, P.; Gondhale, P.; Kulkarni, S.; Musmade, B.; Bhope, S.; Padmanabhan, S. Development and validation of HPLC-UV method for the quantitative analysis of carcinogenic organic impurities and its isomers in the sodium polystyrene sulfonate polymer. Acta Chromatogr. 2020. ahead of print. https://doi.org/10. 1556/1326.2020.00774.

22. Alhusban, A. A.; Ata, S. A.; Shraim, S. A. The safety assessment of toxic metals in commonly used pharmaceutical herbal products and traditional herbs for infants in Jordanian market. Biol. Rrace Elem. Res. 2019, 187, 307-15.

23. FDA, Food and Drug Administration Guidance for Industry: Bioanalytical Method Validation, 2001. https://www.fda.gov/downloads/ drugs/guidances/ucm070107.Pdf, accessed 12th April, 2020. 
24. Etter, J. F.; Zäther, E.; Svensson, S. Analysis of refill liquids for electronic cigarettes. Addiction 2013, 108, 1671-9.

25. Bennani, I.; Alami Chentoufi, M.; El Karbane, M.; Cheikh, A.; Bouatia, M. E-cigarette quality control: impurity and nicotine level analysis in electronic cigarette refill liquids. Sci. World J. 2020, 2020.
26. Raymond, B. H.; Collette-Merrill, K.; Harrison, R. G.; Jarvis, S.; Rasmussen, R. J. The nicotine content of a sample of e-cigarette liquid manufactured in the United States. J. Addict. Med. 2018, 12, 127-31.

27. Davis, B.; Dang, M.; Kim, J.; Talbot, P. Nicotine concentrations in electronic cigarette refill and do-it-yourself fluids. Nicotine Tob. Res. 2015, 17, 134-41. 